\title{
LINGUAGEM E AFASIA: UMA ABORDAGEM DISCURSIVA DA NEUROLINGÜÍSTICA
}

\author{
MARIA IRMA HADLER COUDRY \\ IEL/UNICAMP
}

\section{APRESENTAÇÃO}

Para responder ao convite da Prof $^{a}$. Eni Orlandi - e fazer parte do número temático dos Cadernos destinado à história das idéias lingüísticas, em domínios de estudo da linguagem que compõem uma área de investigação - apresento alguns caminhos ${ }^{1}$ tomados por uma Neurolingüística que têm sua origem traçada por condições históricas, início dos anos oitenta, em nosso Departamento, tempo caracterizado por debates fundantes, nele, de idéias e ideais da Lingüística, em várias de suas dimensões, que abriam novas possibilidades de interfaces - envolvendo uso, funcionamento e conhecimento da linguagem e de sistemas de línguas naturais ${ }^{2}$.

No final da década de setenta, já se realizavam pesquisas envolvendo sujeitos da linguagem (refiro-me especialmente ao Projeto de Aquisição da Linguagem coordenado por Claúdia Lemos). Nessa ocasião, em que se estabeleciam diversas áreas de concentração de pesquisa dos docentes do Departamento na Pós-graduação, a disciplina Análise do Discurso produz farta ferramenta teórico- metodológica para enfrentar as relações do sujeito com o outro, o mundo e a história, organizadas formalmente em uma língua partilhada com outros sujeitos pragmáticos que coloca o sujeito falante na condição de sujeito da linguagem. Dediquei-me a estudar a disciplina AD já sensibilizada pelas questões de subjetividade e de enunciação introduzidas por Émile

\footnotetext{
${ }^{1}$ A referência a "alguns dos caminhos" é pela mais óbvia constatação de que há sempre outros e de que o respeito a diferentes trilhas é um valor fundamental para o genuíno do espírito universitário. Como Cipriano Algor, o oleiro de A caverna, de Saramago, com quem se aprecia como um caminho se torna uma estrada.

${ }^{2}$ Na década de 80 e 90 , muitos de nós docentes do DL contribuímos para mudar a concepção de fato/dado de linguagem (normal e patológica), em contraposição a uma atitude normativa, preconceituosa e desinformada de língua e de linguagem que caracterizava as instituições responsáveis por tais posturas. Fora da Universidade, essa tomada de posição repercutiu no ensino da escrita em diferentes níveis e na avaliação/diagnóstico de patologias em que a linguagem está concernida. Na universidade, repercutiu na inclusão de vários domínios e interfaces da Lingüística na grade curricular da Licenciatura em Letras e do Bacharelado em Lingüística. Mais recentemente, repercutiu na decisão do DL de participar do curso de Fonoaudiologia, partilhando com outros departamentos da Unicamp o novo curso e contribuindo com 8 disciplinas do Bacharelado em Lingüística para uma formação consistente de Lingüística ao futuro fonoaudiólogo.
} 
Benveniste - presentes na língua como um aparelho formal que se relaciona com outros sistemas semióticos não verbais, relação que pode se apresentar como enunciação.

Os caminhos que relato percorrem uma série de princípios teóricos aliados a práticas interativas com sujeitos ${ }^{3}$ afásicos.

Em $1982^{4}$, realizei um estágio ${ }^{5}$ em Neurolingüística na Universidade Livre de Bruxelas, como etapa fundamental para o desenvolvimento de um estudo longitudinal que envolve conhecimentos em áreas muito diferentes da Lingüística (neurologia e neuropsicologia) e aprendi que a Lingüística que se dedica ao estudo da linguagem em funcionamento estava ausente de uma Neurolingüística que se origina na área médica (ver Lebrun, 1983). Essa Neurolingüística segue um modelo organicista de ciência e estabelece uma relação servil com a Lingüística para corroborar suas hipóteses. Muitos textos clássicos, e contemporâneos, de afasia atribuem à linguagem o papel de confirmar achados que inter-relacionam diretamente partes da linguagem a partes do cérebro, e isto sem dúvidas metódicas.

${ }^{3}$ Apresento alguns dados de minha formação acadêmica para que se conheça um percurso que deságua em uma Neurolingüística de tradição Lingüística, ou seja, não organicista por princípio. Fiz o curso de Bacharelado em Lingüística de 1970 a 1973, na Unicamp (1ª turma). Já em 1973, cursei a disciplina Linguagem e Biologia, ministrada pelo Porf. Dr. Armando Freitas da Rocha (tendo sido meu orientador), docente do Instituto de Biologia (IB), Unicamp, crucial para a futtura opção de estudar a relação linguagem/cérebro, no Mestrado. O processo de formação interdisciplinar que a pesquisa de Mestrado exigiu foi uma forma de obter um conhecimento básico (para enfrentar os projetos posteriores) de neurofisiologia e modelos matemáticos de representação (teoria dos autômatas e dos grafos - para representar os diferentes sistemas e espaços neurais e sua dinâmica de funcionamento em diferentes níveis). A partir de 1974, com a ida de Edson Françoso para o IB cursar essa mesma disciplina, formamos um grupo para estudar a relação entre sistemas neurais e linguagem. No Laboratório de Fisiologia Animal, seguimos o desenho experimental da Neurofisiologia (eletrodos, escuta dicótica, gravações com controle de potenciais de ação em polígrafo, relacionando-os com ritmo e sentido). Líamos e discutíamos autores que representam diferentes tendências de abordagem da relação cérebro/linguagem - e os lingüistas do grupo defendiam sempre posturas não organicistas - (1) neurofisiológica, representada por Lenneberg, Ramos Delgado, Bechtereva, Luria, Penfield, Geschwind; (2) matemática e epistemológica, representada por Zadeh, Fodor e Popper; e diferentes abordagens lingüísticas (semântico-pragmáticas, funcionalistas e formais) representadas por Fillmore, Halliday e Chafe. Minha dissertação - Considerações iniciais sobre sistemas neurais e linguagem apresenta um modelo neurofisiológico e matemático do funcionamento do cérebro, em espaços e sistemas neurais, que se correlaciona com um certo modelo semântico, proposto por Fillmore, baseado em cenas cognitivas - experiências do mundo real, ações, objetos, percepções e memórias - que se apresentam como um referencial de situação e que se articulam com referenciais de conceito (esquemas conceituais e categoriais implicados em ações, instituições, objetos) para compor a base para a projeção (criada e ativada pela linguagem, lexicalizada e gramaticalizada) do homem no mundo e vice-versa. Ingressei no Doutorado em Lingüística, no IEL, em 1979, inclinada a prosseguir no estudo da relação cérebro/linguagem.

${ }^{4}$ Em 1981, Edson Françozo e eu fizemos um curso de afasia, na Escola Paulista de Medicina, ministrado pelo Professor Yvan Lebrun, que despertou em mim a vontade de estudar a linguagem na afasia.

${ }^{5}$ Desse estágio (bolsa-sanduíche/CNPq - de fevereiro a agosto de 1982) constavam atividades teóricoclínicas orientadas pelo Professor Lebrun. 


\section{PONTO DE PARTIDA ${ }^{6}$ \\ HÁ SUJEITO NA AFASIA \\ UMA CONCEPÇÃO ABRANGENTE E PÚBLICA DE LINGUAGEM ${ }^{7}$ NA NEUROLINGÜÍSTICA}

Considerando a linguagem como histórica e cultural, e o caráter previamente indeterminado dos processos de significação, assume-se nessa abordagem neurolingüística que a língua resulta da experiência e do trabalho dos falantes com e sobre a linguagem. Língua, nessa concepção, remete para uma atitude frente aos fatos de linguagem segundo a qual as formas linguiísticas se relacionam com os fatores culturais (Possenti, 1995). Esta concepção abrangente de linguagem assume a hipótese da indeterminação da linguagem postulada por Franchi (1976, 1977, 1986) cujos conceitos de atividade constitutiva e trabalho atribuem, sob parâmetros ântropoculturais, ao sujeito (afásico e não afásico) o exercício da linguagem - incompleta e passível de (re)interpetação. Nesse ponto, não afásico e afásico partilham de um sentimento/atitude comum de incompletude frente à linguagem e à língua. Quem nunca passou por situações de se sentir mais incompleto do que usualmente, hesitando, retomando, interrompendo, tendo menos controle sobre o que diz? $\mathrm{Na}$ afasia podem ocorrer várias dessas dificuldades, e outras, com a diferença de ser trabalhoso para o sujeito afásico sair desse "mau momento"; para ele, não se trata apenas de um mau momento que passa. São situações difíceis que o afásico enfrenta, sobretudo levando em conta o grau de tolerância zero que se tem hoje em dia para com os "normais". Imagine-se, então, para com os afásicos. Esse sentimento completamente humano - a incompletude - faz da afasia um fenômeno familiar, reconhecido por quem exerce a linguagem. É evidente que tal posição não é posta para banalizar a afasia mas, ao contrário, para compreendê-la. E compreendê-la do ponto de vista existencial, de um sujeito que abruptamente mudou, e isto lhe causa - e aos seus próximos - desconforto e sofrimento.

A perspectiva discursiva aqui focalizada segue a tradição teórico-metodológica dos estudos que incorporam o sujeito em suas preocupações, ou seja, estudar a linguagem pública, usada por sujeitos que compõem uma comunidade de falantes (que "falam a outros que falam" [Benveniste, 1966]) de uma língua natural, em diversas situações pragmáticas, com diversos propósitos e em vários registros vernaculares, todos legítimos. Fazem parte desses fatores os que conjugam - no processo de atribuição de sentido - as imagens recíprocas entre interlocutores e sobre o referente - o $o$ que e o como se fala - postas e implícitas na dialogia, onde se produzem e se interpretam processos de significação. Do ponto de vista desse autor, isso significa que "o sentido é a condição fundamental que deve preencher toda unidade, em qualquer nível, para ter estatuto lingüístico"(op.cit, p.122).

${ }^{6}$ Refiro-me ao estudo discursivo da afasia realizado em minha tese de doutorado, de 1986, publicada ipsis litteris em livro em 1988: Diário de Narciso: discurso e afasia - análise de interlocuções com afásicos, orientada por Carlos Franchi e co-orientada por Haquira Osakabe.

7 Também assumida nas teses de doutorado de Sírio Possenti, 1986, e Wanderley Geraldi, 1990. 
Neste texto apresento o ponto de partida e alguns portos de chegada de uma abordagem discursiva de Neurolingüística, resultando em uma forma de pensar e de atuar nesse campo de conhecimento e práticas. Uma forma de teorizar que produz uma forma de avaliar e conduzir o processo terapêutico: o movimento teoria-dado-teoria, o dado-achado versus o dado-evidência (Coudry, 1991/1996). Movimento que instrui a avaliação e o acompanhamento do afásico, sob uma dinâmica heurística que produz conhecimento de processos de significação verbais e não verbais. Instrui e produz um (re)conhecimento mútuo de dificuldades e soluções, encontradas na interlocução e dialogia: lugar em que se cruzam discursos e por onde circulam outros sistemas semióticos que partilham com a língua a produção e compreensão de sentidos.

Apresento uma forma de fazer Neurolingüística que considera crucial a contribuição da Lingüística em seu raciocínio e saber técnicos e no estudo da relação normal/patológico: um olhar foucaultiniano, para enxergar o espetáculo da linguagem e para considerar que cada sociedade tem a "doença" que merece, o que coloca a relação normal/patológico em outra ordem de condições. Isto não quer dizer que o afásico não é afásico mas que tem menos afasia do que a avaliação que prescinde da Lingüística evidencia, sob a forma de baterias de testes-padrão que valeriam para qualquer pessoa do planeta.

\section{PORTOS DE CHEGADA: HÁ LINGUAGEM NA AFASIA QUANDO HÁ SUJEITO}

Quem é o sujeito ${ }^{8}$ dessa prática com a linguagem? O sujeito que tem trabalho para exercer com/na/sobre a linguagem em relação ao(s) outro(s) e ao mundo (re)organizado.

Para realizar esse desafio, me envolvi na prática clínica ${ }^{9}$ com a linguagem (avaliação e acompanhamento longitudinal de sujeitos afásicos). Meu primeiro sujeito afásico foi $\mathrm{N}^{10}$, o segundo $\mathrm{P}$ e o terceiro $\mathrm{L}$, cujos dados do acompanhamento longitudinal descrevo e analiso na tese de doutorado.

${ }^{8}$ A dissertação de Ari Pedro Balieiro Junior (2001) apresenta um estudo da subjetividade na afasia, com base no estudo do sujeito SB $O$ sujeito que se estranha: manifestações da subjetividade na afasia. $\mathrm{O}$ autor incorpora o conceito de sujeito psicológico formulado por Orlandi (1966:48): "sujeito psicológico empiricamente coincidente consigo mesmo", interessante para pensar a face existencial do sujeito na afasia que pode ter a peculiar característica de se apresentar cindida, como L, JF, JM.

${ }^{9}$ Realizada de 1983 a 1986 no Serviço de Neurologia Nubor Facure, no Hospital Irmãos Penteado (à época o Departamento de Neurologia da Unicamp funcionava nesse hospital). A partir de 1986, levei essa proposta discursiva ao atendimento ambulatorial do HC/Unicamp, a convite do Prof. Dr. Guilherme Borges e, posteriormente, (1987) dos Profs. Drs. Jaime Maciel e Benito Damasceno, do mesmo departamento, na Unidade de Neuropsicologia e Neurolingüística; a partir de 1998, exerço essa atividade no Ambulatório de Neuropatologia da Linguagem ao qual o CCA está vinculado.

${ }^{10} \mathbf{N}$ de Narciso, por isso Diário de Narciso compõe o título da tese. Também porque é um nome que tem um referente forte, o mito; diferentemente dele, o afásico não se auto-reflete; o espelho d'água reflete o outro: o sujeito 'existencial', com ou sem afasia, precisa do outro; sentir-se estrangeiro e/ou afásico remete mais à imagem de um vidro: transparente e divisor de espaços e perspectivas; e tanto na linguagem quanto na afasia quem se vê de frente é o outro. 
Com $\mathbf{N}$, comerciante, italiano, espetaculoso e alegre, aprendi a interpretar a questão da seleção lexical e nomeação na afasia, a sentir na pele o absurdo que seria se tivesse que proceder a uma avaliação tradicional.

Com $\mathbf{P}$, funcionário público, aprendi a sistematicidade criativa. Sempre de bomhumor, trazendo o jornal da cidade na mão para comentar notícias comigo; sempre que trazia o guarda-chuva, chovia; agenda impecável; tinha gosto por exposições de quadros e trazia na agenda o recorte de jornal anunciando eventos na cidade, para não esquecermos.

Com $\mathbf{L}$, engenheiro e fotógrafo, reservado e de personalidade forte, aprendi a divisão que a afasia pode acarretar na subjetividade (que já é multifacetada), também em termos perceptivos, e como a linguagem na afasia manifesta este estranhamento. Aprendi que a própria linguagem pode atrapalhar e ajudar na produção e compreensão da linguagem.

Acompanhando por anos essas três pessoas afásicas aprendi sobre a instabilidade (sistemática) do fenômeno afásico que, por sua vez, repercute no processo terapêutico; um afásico 'custa um tempão' para dizer uma palavra; de repente fala sem esforço, um minuto depois encontra as mesmas dificuldades. Mas ocorrem também progressos que são para sempre e, assim como a vida, a evolução nunca pára - se o ambiente for favorável ao exercício da linguagem e se não se esperar do afásico o que também não se espera do não afásico. Aprendi o valor da interlocução, de procedimentos metodológicos (que obviamente não precisam ser os mesmos com todos os sujeitos, e podem ser acrescidos de outros) - a agenda, o jornal, o álbum de fotos, o caderno de atividades, a palavra-cruzada, o jogo - bem como do conhecimento e relação mútuos que se estabelecem entre parceiros de tantas situações discursivas partilhadas. Aprendi que nem tudo o que o afásico diz é permeado pela afasia. Há expressões que fazem aparecer o incontrolável (já apontado por Freud; atos falhos e parafasias são produzidos pelo mesmo aparelho de linguagem e suas relações com outros registros). Ocorre que a afasia modifica a neurodinâmica cerebral e pode haver perseverações e menos condições de reconhecimento (restos de linguagem, dizem os clássicos) que podem reduzir o contexto verbal a um só (conforme Jackson).

JF, musicista, ao ler uma manchete da Folha Ilustrada (FSP) "Qual é a música?" leu: Qual é a mu //pausa//, qual é a mulher"; riu e comentou: estava pensando nela. Na ocasião em que analisava o dado ${ }^{11}$ de JF (apresentado, a seguir: Calma que ele fala) saiu uma charge na FSP, entre o primeiro e o segundo turno da última eleição para governador e deputados, em que ACM passava um pito em FHC pelo fato de o PT ter ido bem no primeiro turno. O título da charge é Lição das Urnas e a cena é ACM sentado à mesa do presidente, dizendo Quem manda aqui sou ele. À época, outubro de 1998, era ACM quem mandava em FHC - "sou ele" expressa o lugar que ocupa ACM no poder.

${ }^{11}$ Há várias formatos de apresentação de dados convivendo neste texto. O melhor deles é o adotado pelo Banco de Dados em Neurolingüística (BDN), os do CCA, JF e MG. Os dados de AB e de JM não foram ainda inseridos no sistema BDN (tabela). 
Para mostrar os vários portos a que a Neurolingüística pode chegar, apresento dois dados de uma mesma sessão do $\mathrm{CCA}^{12}$, de 1999, de que Dominique Maingueneau participou, por ocasião do seu séjour em nosso Programa de Pós-graduação. Esses "extratos de sessão" mostram uma dinâmica que ocorre sistematicamente na parte dedicada ao Trabalho de Linguagem, em torno de "fatos contados" - a partir do noticiário escrito e falado - que os participantes trazem para a sessão. É interessante notar como se dá a atribuição de sentido (tema da pesquisa de Iniciação - Fapesp - de Lúcia Scisci) ao que é dito, ou seja, inserido em um cruzamento de vários sistemas semióticos que circulam simultaneamente: linguagem - jornal, TV - , gestos, percepção, conhecimentos partilhados, pressupostos de conhecimento, imagens recíprocas sobre o outro e o referente, imagens e representações visuais, musicais, etc., e em meio à linguagem se apresentando como discurso.

${ }^{12}$ O Centro de Convivência de Afásicos (CCA) correponde a uma proposta conjunta formulada por mim, Edwiges Morato e Benito Damasceno, em 1989, de acompanhamento em grupo de pessoas afásicas em convivência com pessoas não afásicas em diversas situações e práticas discursivas. O CCA é produto de um convênio entre o Departamento de Lingüística (DL) e o de Neurologia (DN), firmado em 1989. Até 1996, fui a docente do DL que deu condições para sua criação e funcionamento do CCA no IEL, bem como responsável pela área de Neurolingüística. O Prof. Dr. Benito Damasceno, docente do DN e a Profa. Dra. Edwiges Maria Morato, à época fonoaudióloga do DN, responderam por esse departamento. A partir de 1996, com a contratação da referida professora pelo DL, dividimos as responsabilidades de docência, pesquisa e extensão/assistência da área de Neurolingüística, do Laboratório de Neurolingüística (LABONE) e do CCA. Atualmente há dois grupos no CCA: a condução do grupo I é de responsabilidade dela e a do grupo II minha. A avaliação e o seguimento neurológico e neuropsicológicos dos integrantes afásicos do CCA são de responsabilidade do Prof. Damasceno. No CCA é realizado um trabalho de, com, na linguagem a partir de uma série de procedimentos metodológicos discursivamente orientados, bem como propostas trazidas pelos sujeitos afásicos, baseados no o que ocorre em nossa vida em sociedade e no o que é noticiado pela mídia, na agenda e em diversos aspectos da vida que compartilham. Cozinhar, ir a exposições, assistir a palestras, também faz parte do conjunto de atividades que praticamos no CCA. Além da linguagem, é realizado um Trabalho de Teatro (por José Amâncio Rodrigues) e de Educação Física (por Flávia Faissal), em que as possibilidades expressivas envolvendo o corpo e a dramatização são vivenciadas em grupo. Veja-se o dado 11. 


\section{Dado I: 12/05/1999 - Participação de Dominique Maingueneau no CCA O enfermeiro, a UTI e a funerária}

\begin{tabular}{|c|c|c|c|}
\hline & Transcrição & $\begin{array}{l}\text { Observações sobre } \\
\text { processos de significação } \\
\text { verbais }\end{array}$ & $\begin{array}{l}\text { Observações sobre processos } \\
\text { de significação não verbais }\end{array}$ \\
\hline JB & Ah, oh, oh, morreu. & & \\
\hline Imc & Morreu... & & \\
\hline JB & Morreu... ah... UTI. & & \\
\hline Imc & Ah! 'Cês viram aquele horror, daquele... & tom: surpresa & \\
\hline Imc & Foi no Rio de Janeiro? & & \\
\hline Imc & No Rio ou em São Paulo? & & \\
\hline $\mathrm{JB}$ & São Paulo. & & \\
\hline Imc & Aquele enfermeiro... que que ele fazia? & & \begin{tabular}{|l|l} 
faz o gesto de injetar uma \\
seringa no braço
\end{tabular} \\
\hline JB & Injetava. & & \\
\hline Imc & Injetava uma substância & & \\
\hline Imc & Não sei o que era & & \\
\hline Imc & Para apressar a morte & & \\
\hline Imc & De várias pessoas & & \\
\hline Imc & Que estavam em estado grave & & \\
\hline Imc & É isso, JB? & & \\
\hline $\mathrm{JB}$ & Eh, eh... & & \\
\hline Imc & Prá que ele fazia isto? & & \\
\hline JB & morreu... & & \\
\hline Imc & $\begin{array}{l}\text { Mas que } \\
\text { Por que, qual era o negócio dele? }\end{array}$ & & \\
\hline $\mathrm{EF}$ & & & faz o gesto de dinheiro \\
\hline Imc & Isto, mas com quem? Fu... & & \\
\hline EF & Funerária & & \\
\hline $\operatorname{Imc}$ & $\begin{array}{l}\text { Ele tinha negócio com uma funerária. A } \\
\text { funerária... é a miséria humana completa. } \\
\text { Ele era enfermeiro de um hospital. É isto? } \\
\text { Aí... a funerária }\end{array}$ & tom: indignação & \\
\hline JB & Pagava & & \\
\hline Imc & $\begin{array}{l}\text { Era... acho que } 80 \text { reais pra pacientes } \\
\text { terminais e traumatizados por acidentes, } \\
\text { era muito mais, era o dobro. } \\
\text { Traumatizados era mais. Aí a faxineira } \\
\text { do... a faxineira que descobriu que } \\
\text { durante o plantão dele... o que acontecia? }\end{array}$ & tom: indignação & \\
\hline JB & Morreu... & & \\
\hline $\operatorname{Imc}$ & $\begin{array}{l}\text { Morriam mais pessoas... aí ela descobriu. } \\
\text { A faxineira, quer dizer, os dirigentes do } \\
\text { hospital nada descobriram. A faxineira } \\
\text { percebeu que morria mais gente durante o } \\
\text { plantão dele. E aí ele fala, né, vocês viram } \\
\text { o depoimento dele? Ouviu isto Shizue? } \\
\text { Não viu? GR viu? }\end{array}$ & tom: indignação & \\
\hline GR & & & Afirma com a cabeça \\
\hline Imc & uma cara de maluco & & \\
\hline
\end{tabular}

Fonte: Banco de Dados em Neurolingüística - BDN - Projeto Integrado/CNPq: 1773/95-4 
Dado II: O tráfico de crianças pelo juiz de Jundiaí

\begin{tabular}{|c|c|c|c|}
\hline & Transcrição & $\begin{array}{l}\text { Observações sobre } \\
\text { processos de significação } \\
\text { verbais }\end{array}$ & $\begin{array}{l}\text { Observações sobre processos } \\
\text { de significação não verbais }\end{array}$ \\
\hline GR & 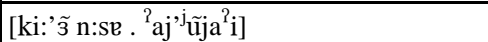 & TF (transcrição fonética) & \\
\hline Imc & Criança em Jundiaí? & & \\
\hline GR & Eh. & & \\
\hline $\mathrm{EF}$ & [ah, eh. & & \\
\hline Imc & Ah, isso eu não sei, que que é? & & \\
\hline $\mathrm{EF}$ & /3is/. & $\mathrm{TF}$ & $\begin{array}{lll}\text { como a investigadora } & \text { não } \\
\text { conhecia a notícia que } & \text { GR } \\
\text { estava tentando contar, } & \mathrm{EF} \\
\text { procura ajudar. } & \end{array}$ \\
\hline Imc & Peraí, deixa eu pegar papel pro seu EF. & & \\
\hline $\mathrm{EF}$ & /zis/. & TF: tentando dizer juiz & \\
\hline Imc & Peraí, peraí que a AP pega pro senhor. & & \\
\hline EF & /3is/. & $\mathrm{TF}$ & \\
\hline Imc & Juiz? & & \\
\hline Imc & $\begin{array}{l}\text { É isso? O juiz, vamo vê agora, que essa } \\
\text { notícia eu não sei qual é. Vamo lá. } \\
\end{array}$ & & \\
\hline Imc & O juiz... & & \\
\hline$\overline{\mathrm{EF}}$ & $/ \mathrm{m} \tilde{\mathrm{d}} \mathrm{do}$ & TF para "mandou" & \\
\hline Imc & Mandô... & & \\
\hline GR & as ki-an-ças. & silabando & \\
\hline Imc & As crianças... & & \\
\hline $\operatorname{Imc}$ & 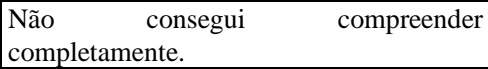 & & \\
\hline $\mathrm{EF}$ & /le-táKa/. & TF: EF tenta dizer "Itália" & \\
\hline EF & /táKa/. & $\mathrm{TF}$ & \\
\hline Imc & Itália? Itália. & & \\
\hline EF & [ oh, oh. & & \\
\hline Imc & Hum... um juiz que vendia, é isso? & & \\
\hline $\operatorname{Imc}$ & Um juiz vendia crianças pra Itália. & & \\
\hline
\end{tabular}

Fonte: Banco de Dados em Neurolingüística - BDN - Projeto Integrado/CNPq: 1773/95-4

O dado III que segue é de uma sessão em que a aluna Luciana Dutra (IC/Fapesp) apresenta, para os participantes do CCA, transcrita ${ }^{13}$ e projetada em tela, uma parte do livro sobre afasia - os depoimentos dos afásicos - que o grupo I do CCA estava escrevendo (hoje já em fase de revisão final para publicação).

${ }^{13}$ Ocorre que à época a notação que o BDN adotava era de tipo "Chico Bento", o que não é necessário (discussão levada, em 2001, ao II Seminário de Neurolingüística, IEL/Unicamp e ao GEL em Sessão Coordenada). 


\section{Dado III: A percepção da dissonância de representação entre a oralidade e a escrita 01/06/2000 - CI: OTRA Ou OUTRA?}

\begin{tabular}{|l|l|l|}
\hline & Transcrição & $\begin{array}{l}\text { Observações sobre processos de } \\
\text { significação verbais }\end{array}$ \\
\hline CI & É otra? Outra? Eu falei otra? & tom - surpresa \\
\hline Ild & $\begin{array}{l}\text { É porque eu estou transcrevendo assim... como a } \\
\text { gente fala. }\end{array}$ & \\
\hline Imc & $\begin{array}{l}\text { Viu CI, a gente não transcreve de acordo com } \\
\text { aquilo que é correto. }\end{array}$ & \\
\hline CI & Eu entendi "outra"? & $\begin{array}{l} \\
\text { Imc } \\
\text { fala assim. Então a gente transcreve do jeito que a } \\
\text { pessoa fala; pra nós lingüistas, do jeito que a } \\
\text { pessoa fala, é o jeito certo de falar. }\end{array}$ \\
\hline
\end{tabular}

Fonte: BDN - Projeto Integrado/CNPq: 1773/95-4

Esse dado revela que a percepção que o afásico tem de sua fala é igual a de qualquer sujeito falante do PB.

\section{$\mathbf{A B}^{14}$}

$O$ estudo da linguagem e da condição de subjetividade de $A B$ foi crucial no conhecimento da expressão da subjetividade ${ }^{15}$ na afasia, estudo que pude iniciar com os dados de L, no Diário de Narciso (que me dizia enquanto eu estava falando com ele: "Você tem que falar pra mim que palavra que é"), inspirada em Benveniste e Osakabe.

$\mathrm{Na}$ primeira sessão $(22 / 06 / 87)$ com $\mathrm{AB}$, notei uma desorientação geral que repercutia nas coordenadas subjetivas que organizam o diálogo (falava ao mesmo tempo que seu interlocutor, vociferava baixinho no turno dele, perdia o contato pelo olhar, o conteúdo de sua fala não correspondia ao tópico), ja que o episódio neurológico era recente. Chamou-me atenção, em meio à desorientação geral de $\mathrm{AB}$, quando lhe pedi para mostrar sua mão direita, que se reportasse a uma parte do corpo, $o$ pé (“deixa eu ver"), para diferenciá-lo da mão.

Nas duas sessões antes das férias orientei a família e trabalhei com o estado geral de $\mathrm{AB}$ : domínio do esquema interacional do diálogo, turnos, olhar, propriocepção,

${ }^{14}$ Referida como A nos estudos iniciais publicados e ABD, em 1987 e 1988, nos primeiros estudos apresentados em congressos e discussões na UNNE. À época tinha 71 anos, brasileira, gaúcha, destra, professora (curso Normal); foi acometida por uma hemorragia intra-cerebral têmporo-parietal esquerda, que resultou em seqüelas lingüístico-cognitivas importantes: hemiparesia direita, sinais de anosognosia, apraxias envolvendo gestos simbólicos e aprendidos; apresentou um quadro de afasia global, na fase inicial pósepisódio neurológico quando manifestou dificuldades com a expressão da subjetividade; evoluiu para um quadro de anomia. As funções corticais superiores foram avaliadas pelo professor Benito P. Damasceno, por meio do protocolo de A. R. Luria. Dei início a avaliação em junho de 1987 e a acompanhei até agosto de 1989.

${ }^{15}$ Neste texto apresento dados de JF e JM que também manifestaram na afasia a subjetividade da/na linguagem. 
percepção e gestos envolvendo o corpo e me lembro de um fato notável. AB era muito vaidosa; gostava de usar brinco, colar, pulseira, esmaltar as unhas, etc. Pedi à família que ela fosse nas sessões "enfeitada" como sempre fez. Foi assim que refez a relação com as partes do corpo, seu nome, função, posição do corpo no espaço e em relação aos objetos e pessoas. Também pedi à família que, nas férias de julho, preparasse um álbum de fotos com cenas de diferentes períodos da vida de $\mathrm{AB}$ (de solteira, no sul, dos filhos pequenos, etc.) Este expediente metodológico (cf. Diário de Narciso, p. 87-88) atua no conhecimento mútuo e faz com que o sujeito também "jogue com as brancas", ou seja, exerça o domínio alternado das iniciativas verbais.

No final de julho e em agosto o trabalho de linguagem com AB se fez em torno do álbum de fotos. Ficamos conversando antes de a sessão começar, ela, eu, o filho e o neto; notei que dizia "ela" para si mesma em várias situações. Gostava de jogar cartas e lhe perguntei se jogora nas férias. Respondeu dizendo "ela jogou”. Perguntei se tinha recebido visita da irmã que morava em São Paulo e ela se confundiu com o ela que se referia à irmã.

Vejam-se os dados:

\section{DADO 4}

03/08/87: Imc e AB olhando fotos antigas dela e seus familiares, no álbum.

Imc - E aqui, nessa outra foto quem é?

$\mathrm{AB}$ - Essa, é meu irmão //hesitação// com, com ela //hesitação//

Imc - Seu irmão com...

$\mathrm{AB}$ - Com ela //risos//.

Imc - Ela quem?

AB - Não sai bem //comentando//.

Imc - Eu e meu irmão.

$\mathrm{AB}$ - Eu e meu irmão.

Imc - Viu? Saiu. E aqui, quem que é?

$\mathrm{AB}$ - Com a Zula e eu e filhos da Zula.

Imc - Seus netos?

$\mathrm{AB}$ - Todos meus netos.

$\mathrm{Na}$ análise desse dado, retomei a reflexão que fizera no Diário de Narciso (p. 5862), iluminada pelos achados do projeto sócio-interacionista de aquisição da linguagem coordenado por Cláudia Lemos e para o qual foram fundamentais as pesquisas desenvolvidas nas teses de doutorado de Ester Scarpa, Rosa Attié Figueira, Cecília Perroni e Maria Fausta de Castro, todas orientadas por ela. Lembrei-me de que Cláudia Lemos se referia à interação dialógica em seus textos e aulas, como sendo constitutiva da própria linguagem; os dados de aquisição mostraram que a incorporação do turno do interlocutor pela criança atua como um ponto de vista estruturante do próprio enunciado, da situação e da construção da realidade, o que também mostraram os dados de N no Diário de Narciso.

Também retomei a reflexão que Lucy Irigaray [citada por Colin MacCabe (1981, p.193)] faz do acesso da criança aa linguagem, como sujeito, pela consciência de 
determinados lugares que pode ocupar na interação apresentada no Diário de Narciso (p. 69) para pensar a questão da reversibilidade da interlocução na afasia, ou seja, do papel que cumpre essa ação pela linguagem, (re)colocando os lugares e (re)tomando a expressão lingüística para manifestá-los. Com a reflexão de Irigaray analiso que a entrada de $A B$ para a linguagem se fez pela porta que o outro abre.

Comentei com a família esse ela e perguntei se também ocorria em casa. Aí me contaram o óbvio: referiam-se a $A B$ sempre como ela, falando dela com ela - e não diretamente com ela, o que dificultava a diferença do $e u$ afásico para o $e u$ não afásico e o outro. Daí em diante nunca mais deixei de comentar essa possibilidade com os familiares e acompanhantes de sujeitos afásicos.

Um dos procedimentos metodológicos que inseri no acompanhamento de $\mathrm{AB}$ - e que lhe ajudou a dizer eu para si mesma e ela para uma pessoa que não está no jogo da interlocução foi formar uma tríade de participávamos eu, $\mathrm{AB}$ e $\mathrm{OD}$, (as duas se conheciam de vista porque se encontravam toda semana no saguão do Ambulatório): essas condições enunciativas ajudaram $\mathrm{AB}$ a formular lingüisticamente sua subjetividade, quando passou a referir-se a si mesma dizendo $e u$, guardando ela para OD, como se vê abaixo.

\section{DADO 5}

25/08/87: Tríade: Imc, AB e OD, na primeira sessão conjunta.

$\mathrm{AB}$ - Agora com ela //referindo-se a $O D / /$, por exemplo, agora eu vi ela falando sempre, achei que tá tudo bem direito.

Imc -Tá direitinho?

$\mathrm{AB}$-Dela, me dá a impressão que ela consegue...

Imc - falar.

$\mathrm{AB}$ - Falar bem, sabe. Eu, tem vezes que eu não consigo falar nada, nada, nada, viu? Às vezes, nada.

Imc - Mas ela também tem vezes que não consegue, não tem, OD?

OD. - É.

AB. - Não consegue às vezes também? //dirigindo-se a OD//

OD - Não.

Imc - Não consegue.

$\mathrm{AB}$ - Pois é.

E vejam como é interessante esta outra interlocução, de $\mathrm{AB}$ com Iem (Edwiges Morato), em que $\mathrm{AB}$ inicia um comentário sobre a sessão em tríade com $\mathrm{OD}$, hesita, reformula e ri flagrando a diferença.

\section{DADO 6}

21/09/1987

$\mathrm{AB}$ - Ela tá bem.

Iem- Ela tá mais animada agora?

$\mathrm{AB}$ - Eu acho, ela, ela come //hesitação//melhor pra //hesitação//melhor pra comer não, melhor do que eu //riso//

\section{[RECORTE]}


De minha parte, os dados de $\mathrm{AB}$ - que se originam de uma prática com e sobre a linguagem - motivada por meus primeiros estudos da linguagem de sujeitoa afásicos (N, $\mathrm{P}$ e L), que derivam da assunção de vários postulados teóricos em torno da linguagem e seu funcionamento (baseados em Franchi, Benveniste, Osakabe, Lahud, Ducrot, de Lemos, Maingueneau e Trudgill), - deram continuidade a estudos discursivos e pragmáticos (enunciativos), revelando-se propícios para o estudo do papel da interlocução na reorganização de condições discursivas em que se exerce a linguagem. Dificuldades com a manipulação e a expressão lingüística da auto-referência (dizer ela por $e u$ ) motivaram a investigação sobre um modelo neuropsicológico ${ }^{16}$, explicativo do quadro cognitivo geral, articulação descrita no texto: Função reguladora da linguagem e operações epilingüísticas: o papel da interlocução na reconstrução da linguagem por sujeitos afásicos ${ }^{17}$. Trabalhamos na articulação da concepção de cérebro desse modelo com a concepção de linguagem (como ação entre interlocutores e como atividade constitutiva) assumida em vários estudos de docentes do Departamento de Lingüística, presente em itens de programa de várias disciplinas que oferecemos na graduação e na pós. No caso da Neurolingüística, seu projeto inicial, contava com uma análise crítica da posição, conceitos e atitudes tomadas em vários estudos de patologia da linguagem em que a Lingüística é tomada à luz de muitos equívocos e para confirmar um raciocínio clínico de tradição organicista.

\section{Afasia: Lingüística e Neurolingüística ${ }^{18}$}

O estudo lingüístico da linguagem de sujeitos afásicos mostra que a afasia afeta a linguagem em um dos seus níveis (fonético-fonológico, sintático, semântico e pragmático), havendo repercussão de um nível sobre o outro no funcionamento discursivo da linguagem (Benveniste, 1966 e Jakobson, 1975), tal como ocorre com a

${ }^{16}$ Refiro-me à concepção dinâmica (por oposição à clássica questão do localizacionismo de funções cerebrais) de funcionamento cerebral formulada pelo neuropsicólogo russo, A. R. Luria, influenciado pelas idéias de L. S. Vygotsky.

${ }^{17}$ Em junho de 1988, eu e Morato e Benito Damasceno apresentamos um estudo conjunto de AB no Encontro da APINEP, em Buenos Aires, Argentina. A articulação do funcionamento discursivo da linguagem com o funcionamento dinâmico do cérebro - um de nossos propósitos - visava a detecção de vias explicativas para processos de significação alterados nas afasias, do ponto de vista da linguagem e da cognição humana. Nesse artigo, analisamos a evolução de determinados aspectos lingüísticos que caracterizam o problema discursivo geral dessa pessoa afásica: a confabulação e a dificuldade com a manipulação lingüística da auto-referência, relacionando a evolução do estado geral inicial que pode caracterizar uma afasia global (afetando linguagem, praxia e percepção) com o papel auto-regulador que a linguagem assume em condições terapêuticas lingüisticamente informadas. Discutimos, também, relações possíveis entre o enfoque neuropsicológico de Luria e uma concepção de linguagem como ação e atividade, no sentido de contribuir para uma formulação lingüística da afasia. Enfocamos também a discussão dos aspectos lingüísticos relacionados à função reguladora da linguagem. Essa articulação está também discutida no texto A ação reguladora da interlocução e de operações epilingüísticas sobre objetos lingüísticos, publicado no Cadernos de Estudos Lingüísticos 5, 117-135, 1988).

${ }^{18}$ Ver texto Lingüística e Neurolingüística, publicado no v. 4, coleção Temas em Neuropsicologia e Neurolingüística, em 1995. 
linguagem não patológica. A afasia se constitui, pois, de alterações em processos de significação relacionados aos níveis lingüísticos e às suas relações e interfaces.

Fortemente marcada pela reflexão sobre os níveis de análise linguística formulada por Benveniste (1966) e por Jakobson (1969), essa formulação para a afasia adquiriu mais precisão quanto ao nível lingüístico alterado e sua repercussão, em outros níveis, no funcionamento discursivo da linguagem. Jakobson (1975), referindo-se a Benveniste como um dos primeiros a propor a importância de estudos estritamente lingüísticos sobre as síndromes afásicas, coloca a afasia como sendo, antes de tudo, uma desintegração da linguagem relacionada ao quadro de um dado nível lingüístico, considerando as relações entre os demais níveis e o todo da linguagem. Essa perspectiva teórica sobre a língua e a linguagem fez com que se percebesse que a afasia afeta tanto um nível quanto sua relação com os demais, no funcionamento discursivo da linguagem. Há sempre repercussão do nível afetado em relação ao todo da linguagem.

Para avaliar e compreender processos de significação, patológicos ou não, que ocorrem na linguagem do sujeito afásico, o que se convencionou chamar de uma teoria de linguagem enunciativo-discursiva. Enunciativo, porque importa a enunciação para o outro, em meio a contingências próprias de uso social da linguagem; discursivo, porque é a forma de a linguagem se expor como atividade significativa, estruturada por fatores ântropo-culturais dissimulados ou aparentes.

A avaliação de linguagem que deriva dessa perspectiva relaciona-se aos processos de descoberta e conhecimento das dificuldades que o sujeito apresenta, bem como aos processos alternativos de significação de que lança mão para com elas lidar. A avaliação leva em conta, por constituir-se em meio às várias práticas discursivas em que o sujeito se engaja, ou pode se engajar, as tendências que a língua pode manifestar quando o sujeito trabalha com os processos patológicos, exibindo a ação criadora afeita ao exercício da linguagem por sujeitos pragmáticos. Na perspectiva teórica que considera avaliação como prática discursiva tomam-se os processos patológicos, explicitados ou não, como o exercício de uma condição particular que se relaciona aos processos normais de significação; e não ao que falta, à falha, ao déficit. Avalia-se o sujeito inserido em uma comunidade lingüística e cultural, em meio a práticas significativas com e sobre a linguagem (relato de fatos da vida pessoal, mostragem de fotos, comentários decorrentes de fatos noticiados etc., o que coloca o sujeito frente à agenda, a jornais, a revistas, ao noticiário) e levando em conta as variedades vernaculares de que se utiliza nas diversas configurações textuais que produz e interpreta.

De acordo com Maingueneau (1987/89, 1990) a formulação do conceito de prática discursiva envolve a reversibilidade essencial entre as duas faces do discurso, a textual (verbal) e a social, e em cujo trânsito se dá a relação da língua com a cultura. Do que se fala? Do que acontece, pode acontecer ou não, do que tem importância, do que se diz, do que se ouve etc. Avaliar significa favorecer que o sujeito exerça diferentes papéis na/da/com (a) linguagem em situações interativas de que participam (no caso) afásico e não afásico; ou seja, entre sujeitos pragmáticos que se apresentam sistematicamente usando a língua nas mais diversas e variadas situações e com diferentes propósitos. Assim é na vida, assim é na afasia. 
Meu trabalho critica a avaliação de linguagem parcialmente realizada e exercida sobre o domínio da tradição escrita normativa, apartada, portanto, do exercício intersubjetivo e social da linguagem, e padronizada para sujeitos ideais. Que chances têm nossos sujeitos afásicos, falantes de variedades vernaculares, se forem avaliados a partir de testes pautados em uma variante padrão veiculada pela escola?

Nesses termos, a questão da avaliação de linguagem em contextos patológicos (afasia), diferentemente da abordagem tradicional assentada em tarefas essencialmente metalingüísticas, descontextualizadas e baseadas em uma concepção normativa e culta de língua, insere-se no exercício de práticas que fazem sentido para o sujeito, relacionadas a situações de uso social da linguagem. Por isso, nessa perspectiva, se avalia como o sujeito expressa sentidos e interpreta o jogo verbal de que participa como sujeito falante de uma língua natural, levando em conta que o sentido não é dado previamente, mas se faz em meio a contingências enunciativas e ântropo-culturais.

Apresentarei, a seguir, dados de sujeitos afásicos (JF, MG e JM) produzidos nessa reversibilidade entre o textual e o social: quando investigador e sujeito afásico tomam contato com as dificuldades e com as tentativas de ultrapassá-las.

\section{JF}

Em nosso primeiro contato, JF expressou um estranhamento de si, do sujeito que passou a ser depois da afasia, o que me fez retomar e formular melhor a hipótese inicial de meus estudos, a de que há dois sujeitos depois da afasia; o que antes dela exercia seus múltiplos papéis - com eficácia (S1) - e aquele que acontece com a afasia (S2). Em lesões centro-hemisféricas e posteriores do cérebro, e também em lesões bilaterais, essa convivência passa por um estranhamento que se explicita verbal e não verbalmente, considerando o papel que as áreas posteriores do cérebro desempenham na percepção, imagem/representação do corpo e gestualidade - mediadas pela linguagem - o que dispõe a avaliação e a atitude terapêutica frente à questão de que há linguagem e sujeito(s) na afasia.

No dado de JF (apresentado, a seguir), Calma que ele fala, a linguagem expressa essa dualidade É nesse sentido que falar de afasia é falar de linguagem e de sujeito, necessariamente concernido em sua condição existencial; e isto diz respeito tanto aos que sabem (entram em contato com) das dificuldades, quanto aos que precisam de mais ajuda para (re)conhecê-las. Para estes últimos - e este é o caso de JF - elas se apresentam como se fossem alheias: a subjetividade na linguagem, inicialmente mitigada e obscurecida pela afasia, se apresenta na forma ela/ele/outro [lembrando Saussure, a língua é forma e não substância] para dizer desse sujeito-outro - que acaba de se instalar. Também ocorre uma cisão em relação ao corpo, derivada da hemiparesia (todo o hemicorpo contralateral à lesão fica abruptamente sem movimento) - que certamente desorganiza as formas de relação proprioceptivas desse sujeito com seu corpo-outro. Quero dizer com isso que é preciso considerar, em uma avaliação discursiva, a relação entre o sujeito, o outro e as realidades simbólicas mediadas pela 
linguagem. E isto é uma decisão de caráter teórico (a afasia é um fato de discurso) com implicações de ordem metodológica (exercício de práticas discursivas).

Como o processo de avaliação descobre essa dupla condição de sujeito de JF?

Na segunda sessão com JF, em 29/03/2000, ele e as duas investigadoras (Imc e Ima) falavam de uma visita de amigos em sua casa a fim de que retomasse suas relações afetivas. JF começou a contar a visita de um amigo no discurso direto, nas próprias falas do amigo, abrindo aspas para introduzi-lo. Eu intervim pedindo-lhe que contasse sem dizer o que o outro disse, mas dizendo o que ocorreu. Foi quando ele disse: calma que ele fala! Ele quem, me perguntei em voz alta? Ele ... esse aqui, levantando levemente o braço parético. Eu, dissemos juntos. O que a forma de contar revela em termos de conhecimento das dificuldades, por um lado, e das possibilidades de lidar com elas, por outro? É interessante que esse dado tivesse ocorrido em meio à passagem do discurso direto para o indireto, lugar discursivo de encontro de múltiplas vozes que devem ser reconhecidas para serem referidas pela linguagem, no eixo da subjetividade. Como JF poderia se referir ao amigo por meio de ele, se refere a si mesmo assim?

Em 05/04/2000, depois de contar muito melhor uma fábula pela segunda vez, já conseguindo identificar e produzir as vozes da enunciação no enunciado, comentou com seus interlocutores (Imc e Ima - a fonoaudióloga) a sua lentidão e de como se saiu nesse processo: 


\section{DADO 8}

\section{JF: 05/04/00 - Comentário sobre relato e sobre si mesmo: Calma que ele fala}

\begin{tabular}{|c|c|c|}
\hline $\begin{array}{l}\text { Sigla do } \\
\text { locutor }\end{array}$ & Transcrição & $\begin{array}{c}\text { Observações sobre as condições de produção do } \\
\text { enunciado - processos de significação verbais e } \\
\text { não verbais } \\
\end{array}$ \\
\hline & & RECORTE \\
\hline $\mathrm{JF}$ & Con- consigo ... & \\
\hline JF & Você sabe ... & \\
\hline Imc & EU! & \\
\hline Imc & Eu quero que você fale EU & \\
\hline Imc & [e não você. & \\
\hline JF & $\mathrm{Eu}$ & \\
\hline JF & Eu si ... eu sinto chegar & \\
\hline $\mathrm{JF}$ & Aí vou falando, vou falando... & ritmo pausado \\
\hline JF & Aí foi aqui ... & mostrando a boca \\
\hline Imc & Isso! & \\
\hline $\mathrm{JF}$ & Ele vai & \\
\hline & [vai contando ... & ritmo pausado \\
\hline $\operatorname{Imc}$ & EU vou contando & \\
\hline JF & Então .. & \\
\hline JF & Esse aqui & mostrando o braço e o hemicorpo paréticos \\
\hline $\mathrm{JF}$ & É tudo, tudo & \\
\hline JF & [não, não & \\
\hline $\mathrm{JF}$ & [calma & ritmo pausado \\
\hline JF & Calma cê aqui & \\
\hline $\mathrm{JF}$ & Deixa & \\
\hline $\mathrm{JF}$ & Deixa eu, deixa eu falar & \\
\hline JF & Aí você vai ... & \\
\hline Imc & Deixa EU falar & chamando atenção por ele ter dito EU \\
\hline Imc & Eh, JF! & \\
\hline Imc & Deixa EU falar! & comemoram as investigadoras Imc e Ima. \\
\hline JF & Cê senta você pra ver & \\
\hline $\mathrm{JF}$ & Porque eu tenho aqui ó ... & referindo-se ao estranhamento diante do que fala \\
\hline $\mathrm{JF}$ & Tem algo falando assim ... & \\
\hline $\mathrm{JF}$ & Algo devagar assim, & ritmo pausado \\
\hline $\mathrm{JF}$ & Assim eu vou & ritmo pausado \\
\hline $\mathrm{JF}$ & [assim agora & ritmo pausado \\
\hline $\mathrm{JF}$ & Se você fala, você fala você fala ... & \\
\hline \multirow[t]{2}{*}{ JF } & \begin{tabular}{|ll} 
& [algo tá falando \\
assim $\ldots$ & \\
\end{tabular} & ritmo pausado \\
\hline & & RECORTE \\
\hline
\end{tabular}

Fonte: Banco de Dados em Neurolingüística (BDN) - Projeto Integrado/CNPq -521773/95-4

O dado de JF mostra os dois sujeitos em ação: S1 passando a conviver abruptamente com uma condição que não conhece e S2 expressando esse desconforto pela linguagem, assim como pela repercussão da hemiparesia na imagem e percepção do próprio corpo. O fato de JF referir a si mesmo por meio de ele (em vez de eu), 
quando toma a palavra no jogo da interlocução, expressa esse estranhamento ${ }^{19}$ e faz "rodar em falso" a reversibilidade de papéis no exercício da linguagem.

Antes de apresentar o segundo dado, cito uma passagem de Pêcheux, 1975, que se ajusta ao estudo da subjetividade na afasia:

“(...) o discurso do sujeito se organiza por referência (direta, divergente) ou ausência de referência, à situação de enunciação (o "eu-aqui-agora" do locutor) que ele experimenta subjetivamente como tantas origens quantos são os eixos de referenciação (eixo das pessoas, dos tempos, das localizações). Toda atividade de linguagem necessita da estabilidade destes pontos de ancoragem para o sujeito; se esta estabilidade falha, há um abalo na própria estrutura do sujeito e na atividade de linguagem". (p.174).

MG

$\mathrm{MG}^{20}$, no início de janeiro, dez dias depois do acidente vascular estava desorientada, lentificada, com hemiparesia do lado esquerdo do corpo, mais leve na face; sem expressão, com dificuldades de deglutição, não se dando conta de que o que falava ninguém compreendia, esforçando-se para entender o que lhe diziam e sem entender direito o que lhe havia acontecido.

Logo na primeira sessão de avaliação, no início de fevereiro, tínhamos estabelecido expedientes metodológicos para atuar com e sobre a linguagem: a agenda, fotos de família e palavras cruzadas. No caso de MG, e para não favorecer que a afasia falasse por ela, foi importante controlar as condições de produção mediante os dados anotados em agenda. Os relatos de afazeres e de cuidados pessoais eram ilustrados por ela com figuras indicativas, coladas à agenda (fotos, recortes de revistas, rótulos), que ajudavam na compreensão mútua e na sua produção verbal. O dado que apresento refere-se ao trabalho com agend ${ }^{21}$ em que o acompanhante marca as atividades que o sujeito realiza durante a semana - que valem a pena ser contadas e eleitas como tema da sessão. É uma fonte de dados para o investigador orientar a avaliação e um material verbal que faz sentido para o sujeito, ou seja, funciona como uma prática discursiva. A

${ }^{19}$ A literatura neurológica e neuropsicológica refere como anosognosia esse estado em que o sujeito não (re)conhece a própria condição patológica. Do ponto de vista lingüístico há desdobramentos dessa condição em relação à subjetividade da linguagem.

${ }^{20}$ MG tem 52 anos, é paulista, agente de turismo recém-aposentada, destra, solteira, com curso de contabilidade. Em 31/12/1999 teve um acidente vascular isquêmico; a Tomografia Computadorizada de crânio, de 23/06/2000, revelou sequiela de AVCi têmporo-parietal à esquerda, além de seqüela de AVCis no tálamo esquerdo e no lobo frontal e AVCi lacunar, na região subcortical da transição têmporo-parietal direita.

${ }^{21}$ A escrita em agenda - expediente metodológico inserido na avaliação e seguimento longitudinal, discursivamente orientados, de sujeitos afásicos (ver Coudry, 1986/88:85-86) tem o objetivo de permitir que o sujeito registre o que vale a pena ser compartilhado com o interlocutor, o que o motiva a produzir processos de significação, alternativos ou não, a despeito da afasia: “(...) a organização dos dados em agenda, enquanto fonte de conhecimento recíproco, permite emergirem fatores pragmáticos de determinação da significação, possibilitando a explicitação das situações envolvidas, a partilha de pressuposições fatuais, o ajuste e a negociação dos conhecimentos não partilhados. (...) a agenda serve para instanciar em discurso processos dialógicos e instigar a utilização de recursos expressivos alternativos”. 
sessão inicia com a investigadora lendo na agenda de MG: Fez escova no cabelo e Andou sozinha.

\section{DADO 9}

\section{MG: 20/03/2000 - Leitura em agenda}

\begin{tabular}{|l|c|l|}
\hline $\begin{array}{l}\text { Sigla do } \\
\text { Locutor }\end{array}$ & \multicolumn{1}{|c|}{ Transcrição } & \multicolumn{1}{c|}{$\begin{array}{c}\text { Observações sobre as condições de produção do } \\
\text { enunciado }\end{array}$} \\
\hline Imc & Fez escova ... & lendo na agenda \\
\hline MG & [no cabelo & mostrando o cabelo \\
\hline Imc & Andou sozinha ... & \\
\hline MG & [andei & \\
\hline MG & Andei sozinha & Sorrindo \\
\hline
\end{tabular}

Fonte: Banco de Dados em Neurolingüística (BDN) - Projeto Integrado/CNPq -521773/95-4

Diante de uma dificuldade que se dá na confluência de eixos que estruturam a cadeia verbal, seja no nível da palavra, seja na estruturação e relação de seus constituintes, falar da coisa, usando o contexto, no sentido de Jakobson, ajuda a 'lubrificar' os processos verbais. Isto tem orientado o sujeito nas escolhas temáticas, ou seja, no o que dizer, favorecendo o como dizer. [Favorece que S1 lide com as dificuldades de S2].

Vejam o que ocorre quando MG introduz um tema que o interlocutor não conhece. A investigadora, $\mathrm{MG}$ e a irmã dela conversavam no hall de entrada antes de dar início a sessão com a fonoaudióloga. MG diz para a investigadora (Imc):

\section{DADO 10}

MG: 11/07/00 - Conversa no hall de espera

\begin{tabular}{|l|l|l|}
\hline $\begin{array}{c}\text { Sigla do } \\
\text { Locutor }\end{array}$ & \multicolumn{1}{|c|}{ Transcrição } & \multicolumn{1}{c|}{$\begin{array}{c}\text { Observações sobre processos de significação verbal e } \\
\text { não verbal }\end{array}$} \\
\hline MG & É melhor dos orelhos! & inicia um tema no hall de espera \\
\hline Imc & Não entendi! & tom de surpresa \\
\hline MG & Nem eu! & tom de humor e rindo \\
\hline & & a irmã comenta o fato de MG querer morar sozinha \\
\hline MG & Eu quero voltar pra casa! & tom de contentamento \\
\hline
\end{tabular}

Fonte: Banco de Dados em Neurolingüística (BDN) - Projeto Integrado/CNPq -521773/95-4

\section{Avaliação discursiva versus avaliação tradicional}

Focalizando o impacto da avaliação na (re)constituição da subjetividade, comparo a avaliação discursiva aqui proposta com a atitude da avaliação tradicional frente ao sujeito e à linguagem.

Que face da língua considerar em uma avaliação discursiva da afasia? O artigo de Ribeiro (no prelo) sobre Quais as faces do português culto brasileiro ajuda nessa tomada de posição. A autora discute a relação do português popular brasileiro com o português culto brasileiro, mostrando que há regras vernáculas e regras cultas e que as segundas são aprendidas historicamente apenas com a escolarização. Que chances têm nossos sujeitos afásicos, falantes de variedades vernaculares, se forem avaliados a partir 
de testes pautados em uma variante padrão veiculada só pela escola? Isso, conforme mostra a autora, considerando os anos de escolaridade da população brasileira, ou seja, $42 \%$ têm até três anos, $31 \%$ têm até sete anos e somente 5,8\% têm 15 anos ou mais. Fenômenos do português popular têm de ser conhecidos por quem avalia e trata de sujeitos afásicos para não serem confundidos com déficit. No dado de JF, que se comenta abaixo, há a ocorrência de você (não patológico) típico e legítimo de certos usos de variedades vernaculares que dão qualidade à dinâmica da interlocução e de vocêlalgo/ele que se originam da cisão de sujeitos causada pela afasia. JF seria considerado confuso já que as coordenadas dêiticas estão suspensas e a referência é difícil de ser identificada. Seria difícil entender e se fazer entender por MG, daí a simplificação com que a literatura apresenta processos dessa natureza como dificuldades de compreensão.

Veja-se pelo que passam os sujeitos em uma avaliação descontextualizada, ahistórica, essencialmente metalingüística e baseada em uma concepção normativa de língua. Há uma prova no sub-teste do Exame do Estado Mental (Folstein et al., 1974), teste utilizado internacionalmente para triagem de sujeitos com 'suspeita' de demência ${ }^{22}$ e aplicado também para afasia, para avaliar se o sujeito compreende ordens, oralmente e por escrito, em que o investigador escreve feche os olhos e pede ao sujeito que faça o que está escrito. Uma senhora de 74 anos (tendo cursado o segundo grau há 60 anos) que está sendo avaliada lê. E erra porque não era isso que tinha que ser feito. Deveria fechar os olhos e não ler. Deveria cumprir a ordem fazendo e não lendo. No entanto, essa senhora passou a vida se relacionando diferentemente com o material escrito, ou seja, lendo e interpretando o que está escrito, e não fazendo. Fico imaginando o que aconteceria a esse examinador se assim procedesse na vida. E essa é que é a questão. Quando viajasse, por exemplo, deveria parar a cada placa onde estivesse escrito Pare no acostamento e ficar por lá para todo o sempre... Aprendemos com a vida e a cultura que o que está escrito é para ser lido e interpretado de acordo com os parâmetros culturais em que nos inserimos e que nos definem como sujeitos pragmáticos, ou seja, enunciativos.

E que repercussão uma avaliação como esta tem na vida do sujeito? Indica, certamente, boas razões para excluí-lo (Foucault, 1971) de prosseguir atuando como sujeito/cidadão.

A avaliação de $\mathbf{J F}$ mostra suas dificuldades com o eixo da subjetividade e com os que a ela se relacionam (coordenadas espaciais, temporais); apresenta dificuldades de natureza semântico-pragmáticas, o que na literatura clássica seria referido como uma afasia de Wernicke.

MG também apresenta uma afasia de tipo posterior (de Wernicke, orientado para uma jargonafasia ${ }^{23}$ ). O interessante é que a avaliação informa como lidar com essa desordem que ocorre na confluência dos dois eixos que estruturam a cadeia verbal (sintagmático e paradigmático), ou seja, um maior controle nas condições de produção (mais contexto) nesse momento de modo que ela e seu interlocutor partilhem de

${ }^{22}$ A senhora avaliada, na entrevista que antecede o teste, se lembra do que se esquece, o que indica razões para não lembrar ou para esquecer que deveriam ser consideradas em sua avaliação.

${ }^{23}$ Ver Morato \& Novaes-Pinto, 1997 e 1998. 
pressupostos que possam ancorar o processo enunciativo (as escolhas paradigmáticas). Através do conhecimento (bem o sentido de diagnóstico) a avaliação mostra como é preciso orientar o processo enunciativo de que MG participa (tendo sido a família orientada nesse sentido). Certamente essa configuração afásica passará por mudanças à medida que MG vá retomando sua condição enunciativa.

\section{Pesquisas}

Apresento, a seguir, o porto de chegada em que as pesquisas desenvolvidas no Projeto Integrado em Neurolingüística/CNPq 1992/2003 - Contribuições da pesquisa neurolingüística para a avaliação do discurso verbal e não verbal ${ }^{24}$, se encontra:

Esse projeto tem dois objetivos:

- $\quad$ a elaboração de um Banco de Dados em Neurolingüística $\left(B D N^{25}\right)$;

- a formulação de princípios e versões protocolares $\left(V P s^{26}\right)$, lingüisticamente informados, de avaliação de processos de significação verbais e não verbais para sujeitos afásicos.

O BDN foi elaborado a partir da transcrição de dados de sessões do grupo I do Centro de Convivência de Afásicos (CCA ${ }^{27} /$ Unicamp), registrados em áudio (de 1990 a 1996; e de 1997 a 1999). Este banco é formado por um sistema de notação e codificação sobre e de processos de significação verbais e não verbais, e suas relações e interfaces, considerando que os dados são produzidos por afásicos e não afásicos, em situações discursivas variadas. Tal banco é construído de modo a preservar as características das variedades vernaculares dos falantes do $\mathrm{PB}$, sem transformar toda a transcrição em 'transcrição fonética'. O BDN tem tentado chegar a um equilíbrio de notação para o 'como se escreve o que se fala' (por exemplo, se alguém fala pobrema, iglesa, truxe, pinas por Campinas, carrocho por cachorro, a transcrição marca os traços desse registro), sobretudo considerando a especificidade de certos dados de afasia e as

${ }^{24}$ Participam do grupo de pesquisa desse projeto 6 docentes do IEL, 1 da FCM, 5 de outras universidades brasileiras, 06 alunos de graduação e 12 alunos de pós.

${ }^{25}$ Ao longo desses 10 anos o CNPq tem mantido bolsistas de IC e Apoio Técnico ao Projeto Integrado que compõem a equipe de transcrição; destaco o trabalho de Cilene Campetela, desde 1996, nessa equipe.

${ }^{26}$ As VPs derivam das pesquisas realizadas nas dissertações e teses defendidas na área, sob minha orientação, e se baseiam no estudo dos níveis lingüísticos envolvidos na afasia e em sua relação com os parâmetros ântropo-culturais. (Re)formulações teórico-metodológicas desenvolvidas nesses estudos contribuem para formulação e análise das VPs. Ver Novaes-Pinto, 1992 e 1999; Morato, 1995; GregolinGuintaste, 1996; Freitas, 1997; Noguchi, 1997; Felizatti, 1998; Pereira, 1998; Freire, 1999; Fedosse, 2000; Mármora, 2000; Padilha, 2000; Balieiro, 2001.

${ }^{27}$ A dinâmica do CCA - sessões de 2000 e 2001 - serviram de fonte de dados para o Projeto Centro de Convivência de Afásicos: práticas discursivas, processos de significação e propriedades interativas apoiado pela Fapesp/ Proc.nº. 99/07055-6, coordenado pela Profa. Dra. Edwiges Morato; ver os relatórios parcial (03/2001) e final (03/2002). No interior desse projeto colaborei, em parceria com Lucilene de Carvalho, com o estudo: Processos de significação e subjetividade - que também contou com a contribuição da pesquisa IC/Fapesp de Lúcia Scisci sobre os processos de significação verbais e não verbais envolvidos na atribuição de sentido no CCA. 
diversas áreas de que provêm os pesquisadores do Projeto. Também integra esse banco um sistema "aberto" de busca ${ }^{28}$, baseado em categorias descritivas e de análise, que orientam a seleção de dados realizada pelos pesquisadores. O sistema de busca do BDN sendo aberto é suscetível a inserções teóricas relevantes para o desenvolvimento do Projeto Integrado e de pesquisas neurolingüísticas que investigam as relações da linguagem com a praxia e a percepção (incorporação da coluna de processos de significação não verbais). A utilização do BDN por pesquisadores tem revelado uma instabilidade necessária em sua configuração, constitutiva do movimento da teoria para o dado e vice-versa. Isto tem se mostrado interessante para o BDN, que se atualiza em relação às pesquisas que se servem dele. É também por esta mobilidade - produzida para incluir categorias de descrição e análise - importantes para pesquisas que envolvem fatores verbais e não-verbais em sua realização - que o BDN não é apenas um depositário de dados.

A análise lingüística dos dados do BDN tem desdobramentos para a elaboração de versões protocolares (VPs), o que mostra, de novo, o movimento cíclico entre dado e teoria; trata-se de pesquisas cujos aspectos não verbais são fundamentais para compreender o sentido do não dito e a relação entre linguagem, práxis e percepção contemplada nos estudos discursivos da afasia .

$\mathrm{O}$ dado 11 mostra as condições atuais do BDN, em tabela.

${ }^{28}$ Veja-se no dado 11 exemplos de categorias: Iges[gestos]; \rir[risos-humor]; Vhes [pausas grandes, retomadas de segmentos fônicos];??[pergunta[). 
BDN: extrato de sessão de Teatro, abril de 1998

\begin{tabular}{|c|c|c|c|c|c|}
\hline & $\mathbf{N}^{\mathbf{0}}$ & $\begin{array}{l}\text { Sigla do } \\
\text { Locutor }\end{array}$ & Transcrição & $\begin{array}{llr}\text { Obs. Sobre as } \\
\text { condições de produção } \\
\text { de processos de } \\
\text { significação verbais }\end{array}$ & $\begin{array}{l}\text { Obs. Sobre as condições } \\
\text { de produção de } \\
\text { processos de significação } \\
\text { não verbais }\end{array}$ \\
\hline & & & & INÍCIO DO RECORTE & \\
\hline l? & 485 & Ijt & Como você mostraria o fogo? & & \\
\hline lges & 486 & SP & & & $\begin{array}{l}\text { SP faz um gesto - com a } \\
\text { mão esquerda fazendo um } \\
\text { movimento. Sobe até a } \\
\text { altura do tronco. } \\
\text { Representa uma labareda. }\end{array}$ \\
\hline lges & 487 & EF & & & $\begin{array}{l}\text { outros sujeitos ajudam } \\
\text { fazendo o mesmo gesto de } \\
\text { SP mas com mais rapidez } \\
\text { e sincronia, fornecendo } \\
\text { mais detalhes do fogo } \\
\text { subindo em labareda. }\end{array}$ \\
\hline $1 ?$ & 488 & Ijt & $\begin{array}{l}\text { como o senhor mostraria isso } \\
\text { usando só gestos? }\end{array}$ & & \\
\hline 1 & 489 & Ijt & vamos começar do começo... & & \\
\hline 1? & 490 & Ijt & \begin{tabular}{|l}
$\begin{array}{l}\text { como você põe fogo em } \\
\text { alguma coisa? }\end{array}$ \\
\end{tabular} & & \\
\hline lges & 491 & SP & & & $\begin{array}{l}\text { Faz o gesto de riscar um } \\
\text { fósforo e coloca fogo em } \\
\text { um monte de folhas no } \\
\text { chão. }\end{array}$ \\
\hline 1 & 492 & Ijt & $\begin{array}{l}\text { usa a outra mão pra ajudar a } \\
\text { acender! }\end{array}$ & & $\begin{array}{l}\text { Dirige a ação para que SP } \\
\text { demonstre que acendeu o } \\
\text { fogo e este se espalhou } \\
\text { para representar um } \\
\text { incêndio. }\end{array}$ \\
\hline Thes & 493 & $\mathrm{SP}$ & \begin{tabular}{|lll} 
fogo... & floresta... & bicho... \\
índios... & & \\
\end{tabular} & $\begin{array}{l}\text { tom: enumerativo. } \\
\text { SP tenta dizer que o } \\
\text { fogo atingiu a floresta e } \\
\text { se propagou matando as } \\
\text { árvores, os animais e os } \\
\text { índios. }\end{array}$ & \\
\hline $1 ?$ & 494 & Ijt & como você mostraria os índios? & & \\
\hline lges & 495 & $\mathrm{EF}$ & & & $\begin{array}{l}\text { EF faz um gesto circular } \\
\text { demonstrando que existe } \\
\text { algum adereço na cabeça }\end{array}$ \\
\hline 1? & 496 & Ijt & $\begin{array}{l}\text { o que que os índios fizeram } \\
\text { para parar o incêndio? }\end{array}$ & & $\begin{array}{l}\text { EF representa a dança da } \\
\text { chuva por meio de gestos }\end{array}$ \\
\hline 1 & 497 & SI & [rezaram! & & \\
\hline & 498 & $\mathrm{CF}$ & & CF começa a cantar & CF começa a dançar \\
\hline Irir & 499 & SI & ave-maria... & Risos & \\
\hline 1 & 500 & $\mathrm{CF}$ & & CF segue vocalizandor & CF segue dançando \\
\hline & & & & FIM DO RECORTE & \\
\hline
\end{tabular}

Fonte: Projeto Integrado em Neurolingüística/CNPq - Banco de dados (BDN) 
Já, a elaboração de VPs de avaliação de processos de significação verbais e não verbais se referem aos níveis de funcionamento da linguagem e sua relação com a cultura; e são baseadas em formulações teóricas (indeterminação da linguagem) e metodológicas (práticas discursivas) apresentadas em dissertações e teses na área de Neurolingüística. A produção de VPs traz à tona a reflexão sobre a relação normal/patológico considerando a dinâmica da oralidade - diferente do que a visão tradicional entende por "oral/fala" -, o funcionamento da linguagem, quando ocorre também a inter-relação com outros sistemas semióticos não verbais e a natureza/qualidade das interações entre afásicos e não afásicos.

\section{$O$ caso $\mathbf{J M}^{29}$ : Linguagem, gestos e percepção}

Como fecho deste texto, apresento as primeiras reflexões ${ }^{30}$ sobre um caso que estou acompanhando desde maio de 2001.

A "experiência sensível” com afásicos tem mostrado que o trânsito de processos de significação verbais e não verbais na afasia é normal; também na afasia circulam relações entre linguagem, gestos e percepção que atuam na (re)organização da nova ordem (Goldstein, 1995; Canguilhem, 1995, Vygotsky, 1984, Bakhtin, 1992 e Luria, 1977). Mas o sujeito sempre pode sublinhar (Foucault, 1961) e inscrever outra ordem; fabricar outros trajetos e o cérebro registrar essa atividade psíquica (Luria, 1976).

Do ponto de vista da semiologia clássica, JM apresenta uma afasia de Wernicke, com presença de jargões e parafasias, uma Jargonafasia, e dificuldades de compreensão.

Na avaliação de JM percebi que as dificuldades de produção dos sons da língua e dos gestos articulatórios se relacionam com a percepção: JM se beneficia do reconhecimento proprioceptivo e de feixes de associações que fomos construindo nessa heurística básica para (re)ordenar e fixar sequiências de gestos articulatórios envolvidos em segmentos fônicos. Tal dificuldade se manifesta como uma apraxia para os gestos articulatórios, uma desordem de natureza gnósica (e não motora). De acordo com Luria $^{31}$, trata-se de uma afasia acústico-gnósica.

${ }^{29}$ JM, médica, destra, baiana, 52 anos, 3 filhos e em 30/04/2001 sofreu um AVCi (Acidente Vascular Cerebral isquêmico) agudo acometendo os lobos temporal e parietal esquerdo, com efeito de massa deslocando a linha média contralateral (cf. laudo de Tomografia Computadorizada de Crânio, realizada em 05/05/2001).

${ }^{30} \mathrm{E}$ que me fizeram retornar a reflexões já esboçadas no primeiro estudo de caso que realizei em Bruxelas, em 1982, MB, em parceria com Luc De Vreese. MB, uma artista plástica que passava por um processo de demencição por metástese cerebral, cujo desenvolvimento da doença acompanhamos: a cada dia uma perda que se relacionava com outra(s). Chega-se a um ponto em que a linguagem não serve mais para organizar a vida mental; não há mais trânsito entre a linguagem e outras funções psíquicas; entre a linguagem, ações e processos, gestos, percepção e reconhecimento; o sujeito não se lembra do que esquece; todo o aprendizado, a culturação, o conhecimento se esvai e todos os sintomas neuropsicológicos (non sense, apragmatismo, agnosias, apraxias) aparecem. Não há mais sujeito, não há mais linguagem, não há mais referência.

${ }^{31}$ Existe uma questão de ordem/sintaxe na apraxia. Luria, 1977, já apontou essa relação quando diferencia a Afasia Motora Aferente (AMA) da eferente (AME). Como parte do projeto de estudos 
Observei durante quase um ano de seguimento longitudinal (domiciliar, com perspectivas de este ano ela aceitar participar do CCA), por um lado, a lógica da linguagem na afasia (formulação desenvolvida no estudo de caso de SB, em Coudry, 1997) e, por outro, a instabilidade do fenômeno afásico: há situações em que JM é afásica, há outras em que parece mais afásica do que é, e outras, ainda, em que a afasia não se manifesta. Apresenta também, dada à agnosia (a síntese do que fala e escuta), algumas dificuldades para interpretar e compreender o que o outro lhe diz, bem como para entender o que lê; perde muitos detalhes do texto mas mantém a compreensão geral. Relendo várias vezes, tem conseguido compreender mais. Quando lê em voz alta, os jargões se manifestam em profusão e quase não se identificam palavras de nossa língua (parece outra língua, na maioria das vezes seguindo o padrão do PB).

Uma hipótese de Freud ${ }^{32}$, apresentada em sua tese de doutorado, de 1891: "Ueber Aphasie" - La Afasia - a relação entre associação e percepção (não há uma sem a outra) - é tomada nesta tentativa de síntese (da linguagem com a gestualidade e a percepção). Se a percepção (agnosia) está alterada também as associações com as palavras da língua manifestam essa alteração (afasia). Tenho percebido que o jargão se apresenta ora como palavras que não são da língua, ora se aproximando das palavras da língua; percebo mudanças na sua configuração (quandi [quando], com voça [com você], idoda [idade], eu quêro [eu quero], comiga [comigo], megas [amigas médicas], todos uns amigas [todas as amigas], tá cheganda [chegando]), mulheras [mulheres]; ou seja, o jargão (que "evolui" para um conjunto de parafasias) vai se aproximando das palavras da língua, se "morfologizando", apresentando marcas do PB de gênero, número/flexão, aspecto. Segundo Freud (op.cit.), JM apresenta uma afasia mista assimbólico-verbal (clinicamente identificada como um quadro de Wernicke).

No caso de JM, é na ordem (em sequiência) que as dificuldades com os gestos articulatórios ocorrem. Também é essa mesma (des)ordem que se manifesta na praxia que envolve a representação de ações com o corpo e objetos - e ela fala enquanto $f a z$. Entretanto, quando se propôs a me examinar porque eu estava com dor de cabeça (e nunca tenho), não apresentou qualquer dificuldade com as ações envolvidas no exame clínico (auscultar, medir a pressão, etc.) e sua fala, com e sem afasia, se encaixava melhor à situação.

Quando embaraçada com a ordem dos segmentos fônicos de uma palavra, JM se beneficia se o interlocutor alongar um deles: parece que o alongamento "guarda o lugar" para o bom caminho, impedindo outros de se anunciarem. Tal reflexão aponta para que se considere normal a relação da linguagem na afasia - consigo mesma - e com outros processos cognitivos (praxia e percepção). Há trânsito (simultâneo) entre processos de significação verbais e não verbais, também na afasia, circulação que muitas vezes ajuda, outras, atrapalha (como para os não afásicos, vide os inúmeros atos falhos que vivemos cometendo): se por um lado, o fenômeno da afasia é estável na sua 'estrutura' (configuração), por outro, é instável na sua expressão (o que pode ocorrer

lingüísticos para a área de Neurolingüística orientei três estudos que discutem essa questão: Freitas, 1997; Fedosse, 2000; Mármora, 2000, ou seja, a ordem em vários níveis afetando processos fonológicos e lexicais.

${ }^{32}$ Ver pesquisa de Mestrado Lucilene de Carvalho, 2001. 
com não afásicos, embora estes tenham mais condições de retomar, corrigir, dizer de outras formas etc.).

Para 'dramatizar' a subjetividade na afasia, trabalhei com sketches ${ }^{33}$. O trabalho de encenação de sketches tem a seguinte motivação teórico-metodológica: envolve a representação de cenas enunciativas (Maingueneau, 1989 - o que me remeteu a Fillmore) que mobilizam processos de significação verbais e não verbais. Trata-se de situações pragmáticas partilhadas por interlocutores de uma dada comunidade lingüística (uma cena entre patroa e empregada, alguém que bate à porta, um telefone que toca, uma carta que chega etc.). A proposta terapêutica de vivenciar uma cena do mundo - que pode ser expressa verbalmente de muitas formas - possibilita ao sujeito uma projeção do que pode e consegue dizer, usando de fato a linguagem para isto, lidando com a linguagem e a afasia, em meio às formas que a língua dispõe - e as que permite ou não "criar" (força criadora da linguagem) - e às coordenadas da situação pragmática em questão. Por essa atividade se avalia a linguagem em funcionamento em todos os seus níveis, ou seja, os processos verbais relativos ao sistema lingüístico (fonológicos, sintáticos, semânticos), bem como à relação da língua com parâmetros ântropo-culturais (processos semânticos e pragmáticos).

É interessante observar como JM, durante o desenvolvimento do sketch, improvisa o que dizer, como um sujeito não afásico faria, e se sai bem no jogo dialógico em que se ocorre a atribuição mútua de sentido.

Vejam-se os “dados-achados”

\section{DADO 12}

\section{Data: 10/10/01}

Imc : [ Vamos, vamos fazer outro sketch ... eu vim fazer uma limpeza aqui na sua casa, uma faxina, você não gostou, deixei tudo sujo, imundo e você vai me mandar embora.

$\mathrm{JM}$ :

[ H $\tilde{A}$... sujo, jugo.

Imc : Sujo.

JM : Xuga.

Imc : S: s: s: s: su: su:

JM : Joi.

Imc : Então cê num gostou do meu serviço, cê vai me mandar embora, tá ? Então eu, eu vô até o fim do dia, vou pedir o dinheiro e cê vai falar não, não.

$\mathrm{JM}:$ O meu dinheiro.

Imc : Não vai me dá o dinheiro.

JM : Vô dinheiro pro cê não.

Imc : Vai mostrar que tá tudo sujo e vai me mandar embora, tá ?

JM : [ Não.

${ }^{33}$ Esse trabalho me remete ao início do anos setenta, quando comecei a dar aulas de francês na Unicamp, ao que aprendi com Cida Coudry quando vivenciávamos em sala de aula situações do dia-a-dia francês, pragmaticamente, com todos os traços culturais presentes - bufando, reclamando, raciocinando de modo cartesiano etc. - de modo que os alunos não se sentissem tão estrangeiros (o que os aproxima de algumas situações por que passam os afásicos), sobretudo em situações de improviso. 
Imc : Tá bom ? Então cê tá aí sentada fazendo suas coisas e eu chego aqui ... Oh, dona Jaci, eu já acabei o serviço oh, e agora quero o meu dinheiro porque tô indo embora.

JM : Tá.

Imc : Eu volto a semana que vem, tá bom ?

JM : Dona Maria ...

Imc : [ Já acabei tudo, fiz tudo.

$\mathrm{JM}:$ Ah, ah sua amiga?

Imc : Eu fiz tudo !

JM : Você é o ...

Imc : Eu sou a faxineira que acabei de ...

JM : Ibegê.

Imc : Aí você vai revistar, vai ver ...

JM : Vige ! Tá tudo limpo aqui ! Ave ! Oh largou isso aqui, num podia tá aqui, tudo banho, tá tudo berano, tudo taqui, tudo rimpa ...

Imc :

[ Ah, mas eu fiz como a senhora mandou.

$\mathrm{JM}:$

[ Ah não ! Num vou dar de...

Imc : Ah, eu quero cem real, cem real.

JM : Não senhora.

Imc : Cem real.

JM : Vou te dá só o dinheiro pro cê morá.

Imc : Pra ir de ônibus?

JM : [ Só, só isso !

Imc : Embora daqui.

JM : [ E mai nada.

Imc : Não dona Jaci, eu trabalhei o dia inteiro !

$\mathrm{JM}:$ Ah, mas eu pregada aqui tudo.

Imc : Como não ? Olha aqui !

JM : Tudo sujo, tudo sujo !

Imc : Sujo ?

JM : Tudo luxujo !

Imc : Como que a senhora ...

JM : [ [ [ ] não, pode embora, não quero mais você, não quero com você mais !

Imc : Não, não.

JM : Não, vão embora com você.

Imc : [ Não, tenha dó !

JM : Não, toma o dinheiro.

Imc : [ Pelo amor de Deus !

JM : Não, não.

Imc : Olha aqui, o banheiro eu limpei, vai lá ver.

$\mathrm{JM}:$ Tá sujo !

Imc : Num tá ...

JM : Tá sujo não, tá imundo ! Tudo bilado, tudo, tudo.

Imc : Mas a senhora, a senhora não me contratou ? A senhora tem que me pagar !

JM : Não, avisa ela, eu farei pra ela pra ... eu estou farando ... 
Imc : Pra limpar.

JM : Imbás ... comos ...

Imc : A senhora me contratou pra eu fazer a faxina.

JM : Isso !

Imc : Eu fiz, eu quero o dinheiro !

$\mathrm{JM}$ : //initeligível por sobreposição de vozes// Eu quero dinheiro, num vou dá dinheiro !

Imc : Quero meu dinheiro senão vou chamar a polícia.

JM : Oh, vá chamá bajá, vá chamá, vá chamá do began dá nos homi que fará no ... nos outro memo, nos homi.

Imc : //risos// polícia.

$\mathrm{JM}$ : Não ... e que as pessoas tras as moças que que tem, que tem dinhei ...

Imc : Sindicato?

JM : É.

Imc : Vou lá no sindicato.

JM : É, vou trabalho beganje.

Imc : A senhora vai no sindicato?

JM : Vou.

Imc : Tá bom, então me dá o dinheiro da condução que eu vou embora fugir pra minha terra.

$\mathrm{JM}: / /$ risos//

Os dados que apresento neste texto explicitam uma aborgagem enuciativodiscursiva de Neurolingüística que, ao contrário da visão organicista e psicométrica de linguagem, toma língua, discurso e cognição como construtos humanos que se relacionam.

Apresento, por fim, trechos de uma sessão em que JM expressa a subjetividade na afasia.

\section{DADO 13}

Data: 09/10/2001 Sketch: Imc representa ser alguém que bate à porta, JM atende e se apresenta dizendo "eu estou JM".

JM: Eu estou Jaci

Imc: Eu sou Jaci.

JM: Jaci.

Imc: Eu sou.

JM: Eu estou.

Imc: Sou. Vamos lá.

JM: Jaci fala.

Imc: Vamos lá. Sou.

JM: Sou.

Imc: Sou.

JM: Jô.

Imc: Não sou sou

JM: sou. 
Imc: Eu

JM: E

Imc: Eu

JM: E

Imc: EU

JM: EU

Imc: Sou

JM: Estou

Imc: Sou

JM: Estou

(RECORTE)

Imc: Eu estou aqui.

JM: Eu estou aqui

Imc: Estou aqui

JM: Estou aqui

Imc: Agora Eu sou a Maza.

JM: Estou Ja ele é ele a

Imc: Fala você é a Maza.

JM: Você fala.

Imc: Você É

JM: Ele ele

Imc: Não fala você

JM: Ela, ela

(RECORTE)

JM: Eu Jacis.

Imc: Eu sou Jaci

JM: Jacis

Imc: Eu sou

JM: Eu estou

Imc: Que interessante, né ? Porque: Agora vamos pensar no sentido disso. Por que que você fala eu estou Jaci? Porque você tá diferente?

JM: É

Imc: Não é a mesma.

JM: É.

Imc: É isso?

JM: É. Pode ser.

Imc: Pode ser. Não é a mesma Jaci.

JM: É. Eu num sou, né?

Imc: Num

JM: Eu sou Jaci

Imc: Você é Jaci.

JM: É. Eu.

(RECORTE)

Imc: Eu sou Jaci 
JM: Estou. Eu estou: outra...pessoa.

Imc: Eu estou outra pessoa. Olha o que você falou, Jaci ? Eu estou outra pessoa. JM: Foi?

Imc: Foi. Quer dizer você a dificuldade de falar eu sou Jaci é porque você se sente ... JM: que não era ela. É.

\section{BIBLIOGRAFIA}

BALIEIRO, A.P.J. (2001). O sujeito que se estranha: manifestações da subjetividade na afasia. Dissertação de Mestrado, co-orientada por Ester Scarpa. Campinas, Dep. de Lingüística, IEL, Unicamp.

BAKHTIN, M. (1984). Marxismo e Filosofia da Linguagem. São Paulo: Hucitec.

BENVENISTE, E. (1966). "Da subjetividade na linguagem", in Problemas de Linguística Geral, vol. I. Trad. De Maria da Gloria Novak e Luiza Neri, São Paulo: Cia. Ed. Nacional e Ed. da USP (original de 1958).

CANGUILHEM, G. (1995). O normal e o patológico, Rio de Janeiro: Forense Universitária.

CARVALHO, L. (2001). Zur auffassung der aphasien: a vigência de Freud para o estudo lingüístico das afasias. Dissertação de Mestrado. Campinas, Dep. de Lingüística, IEL, Unicamp.

COUDRY M.I.H. (1986/88). Diário de Narciso: discurso e afasia. São Paulo: Martins Fontes. "Lingüística e Neurolingüística". In B.P. Damasceno \& M. I. Hadler Coudry (orgs.). São Paulo: SBPn, 12-19.

(1991/96). “O que é dado em Neurolinguística?”, in Maria Fausta C. Pereira de Castro (org.), O método e o dado no estudo da linguagem, Campinas: Editora da UNICAMP, 179-194.

COUDRY M.I.H. \& POSSENTI, S. (1983). "Avaliar discursos patológicos, in Cadernos de Estudos Lingüísticos, 5, Campinas, IEL, UNICAMP, 99-109.

COUDRY M.I.H. \& MORATO, E.M. (1992). "Processos de significação: a visão da Neurolingüística", in ABRALIN, 13, São Paulo, 59-73.

COUDRY M.I.H. \& GANDOLFO, M. C. (1994). “Afasia Pragmática?”, texto apresentado no I Congresso Internacional da ABRALIN, Salvador (mimeo).

(1997). "Condições de subjetividade e patologia cerebral", texto apresentado no II CELSUL, Forianópolis.

. (1997b). "Língua, discurso e a lógica da linguagem patológica", in Cadernos da F.F.C., v. 6, n.2, 131-148.

DAMASCENO, B.P. (1990). "Neuropsicologia da atividade discursiva e seus distúrbios", in Cadernos de Estudos Linguísticos, 19, Campinas, IEL, UNICAMP, 147-157.

. (1997). "Neuropsicologia e Neurolingüística", in Cadernos de Estudos Lingüísticos, 32, Campinas, IEL, UNICAMP, 87-92.

DUTRA, L.S. (2001). A repercussão da afasia na vida de sujeitos afásicos e familiares (Projeto FAPESP: 00/00349-3).

FEDOSSE, E. Da relação linguagem e praxia: estudo neurolingüístico de um caso de afasia. Dissertação de Mestrado. Campinas, Dep. de Lingüística, IEL, Unicamp. 
FELIZATTI, P. (1998). Aspectos fonético-fonológicos da disartria pós-traumática: Um estudo de caso. Dissertação de Mestrado. Campinas, Dep. de Lingüística, IEL, Unicamp.

FOLSTEIN, M., FOLSTEIN, S. \& McHUGH, P. (1974). Mini Mental State, in Journal Psychiat., v. 12, p. 189-198.

FOUCAULT, M. (1961). Doença mental e psicologia. Rio de Janeiro: Tempo Brasileiro. . (1969/1995). Arqueologia do saber. São Paulo: Forense Universitária. (1971). L'ordre du discours. Paris: Gallimard.

FRANCHI, C. (1977). "Linguagem - Atividade Constitutiva", in Almanaque, 5, São Paulo: Brasiliense, 927. . (1986). "Reflexões sobre a hipótese da modularidade da mente", in ABRALIN, 8:17-35.

FREIRE, F.M.P. (1999). "Enunciação e discurso: a linguagem de programação Logo no discurso do afásico". Dissertação de Mestrado. IEL/UNICAMP.

FREITAS, Margareth de Souza. Alterações fono-articulatórias nas afasias motoras: contribuições para uma caracterização lingüística da afasia. Tese de Doutorado. Campinas, Dep. de Lingüística, IEL, Unicamp.

FREUD, S. (1891/1973). La afasia. Buenos Aires: Nueva Visión.

GERALDI, J.W. (1990). Portos de Passagem. São Paulo:Martins Fontes:

GANDOLFO, M.C. (1994). "Síndrome frontal (leve) ou afasia semântico-pragmática". Dissertação de Mestrado. Campinas, Dep. de Lingüística, IEL, Unicamp. Publicada em livro (1996) Às margens do sentido, São Paulo: Plexus.

GHENCEV, R. (2002). Um estudo comparativo da jargonafasia (Projeto FAPESP: 01/07583-4)

GOLDSTEIN, K. (1995). The orgasnism.New York: Zone Books.

GUINDASTE, R.M.G. (1996). "O agramatismo: um estudo de caso em Português”. Tese de Doutorado. Campinas, Dep. de Lingüística, IEL, Unicamp.

JACKSON, H. (1931-32/77). "Huglings Jackson's doctrine of aphasia”, in W. Riese Selected papers on the history of aphasia. Amsterdam: Swets \& Zeitilinger, 100-121.

JAKOBSON, R. (1969). "Dois aspectos da linguagem e dois tipos de afasia", in Lingüística e Comunicação. São Paulo: Cultrix, 34-62.

(1975). "Les règles des dégâts grammaticaux" in Julia Kristeva, Jean-Claude Milner et Nicolas Ruwet (dir.), Langue, discours, société. Paris: Seuil, 11-25.

LAHUD, M. (1979). A propósito da noção de dêixis. São Paulo: Ática.

LEBRUN, Y. (1983). Tratado de Afasia, São Paulo: Panamed, 9- 19, 35-39, 97-105.

LURIA, A.R. (1976). Basic Problems of Neurolinguistics. The Hague: Mouton. . (1977). Neuropsychological Studies in Aphasia, Amsterdam: Swets \& Zeitlinger B. V.

MACCABE, C. (1981). On discourse, in MacCabe (org.), The talking cure: Essays in Psychoanalysis. London: The McMillan Press. 
MAINGUENEAU, D. (1987/89). Novas Tendências em Análise do Discurso, Campinas: Pontes. . (1990) L'Analyse du Discours - introduction aux lectures de l'archive. Paris: Hachette.

MÁRMORA, C.H.C. (2000). "Linguagem, afasia, (a)praxia: uma perspectiva neurolingüística”. Dissertação de Mestrado. IEL/UNICAMP.

MORATO, E.M. (1995). "Um estudo da confabulação no contexto neuropsicológico: O discurso à deriva ou as sem-rezões do sentido". Tese de Doutorado; co-orientada por Ingedore Villaça-Koch. Campinas, Dep. de Lingüística, IEL, Unicamp.

MORATO, E.M. \& COUDRY, M.I.H. (1992). "Digressão e confabulação na afasia: as formas marginais do dizer”, in Estudos Linguísticos XXI, Jaú, 644-651.

MORATO, E.M. \& NOVAES-PINTO, R. (1997). “ A relação entre neologismo e jargonafasia: implicações neurolinguísticas (apresentado no II Círculo Linguístico do Sul/CELSUL).

(1998). "Aspectos Enunciativos da Jargonafasia" - Caderno de Estudos Linguísticos XXVII , p. $396-401$.

NOGUCHI, M.S. (1997). A linguagem da doença de Alzheimer: considerações sobre o modelo de funcionamento lingüístico cognitivo. Mestrado em Neurociências, Unicamp. Orientador: Prof. Dr. Benito Pereira Damasceno, Co-orientadora: Prof $^{a}$. Dr ${ }^{\mathrm{a}}$. Maria Irma Hadler Coudry.

NOVAES PINTO, R. (1999). A contribuição do estudo discursivo para uma análise crítica das categorias clínicas. Tese de doutorado (inédita). IEL/UNICAMP.

ORLANDI, E. (1996). Interpretação: autoria, leitura e efeitos do trabalho simbólico. Petrópolis:Vozes.

OSAKABE, H. (1979). Argumentação e discurso político. São Paulo: Kairós.

PADILHA, A.M.L. (2000). Bianca: o ser simbólico: para além dos limites da deficiência mental. Mestrado em Educação, Unicamp. Orientador: Prof. Dr. Angel Pino Sirgado, Co-orientadora: Prof ${ }^{\mathrm{a}}$. Dr ${ }^{\mathrm{a}}$. Maria Irma Hadler Coudry.

PÊCHEUX, M. \& FUCHS, C. (1990). "A propósito da Análise Automática do Discurso: atualização e perspectivas (1975)". In Gadet \& Hak (orgs.) Por uma análisre automática do discurso. Uma introdução à obra de Michel atualização e perspectivas. Campinas: Ed. da Unicamp.

PEREIRA, S.E. (1998). Um estudo do fenômeno da relevância no discurso patológico. Dissertação de Mestrado. Campinas, Dep. de Lingüística, IEL, Unicamp.

POSSENTI, S. (1986/88). Discurso, estilo e subjetividade. São Paulo:Martins Fontes. (1995). "Língua: sistema de sistemas", In B.P. Damasceno \& M. I. Hadler Coudry (orgs.). Temas de Neuropsicologia, vol. IV. São Paulo: SBPn, 20-25.

POSSENTI, S. \& COUDRY, M.I.H. (1991). “A relevância de piadas em protocolos de afasia”, in Estudos Linguísticos XVI, Anais de Seminários do GEL, Franca: 725-732.

RIBEIRO, I. Quais as faces do português culto brasileiro? (a sair).

SCISCI, L. (2002). Estudo da atribuição de sentido em contextos interativos envolvendo processos de significação verbais e não-verbais de sujeitos afásicos e não afásicos (Projeto FAPESP: 01/011797).

VYGOTSKY, L.S. (1988). A formação social da mente. São Paulo: Martins Fontes. 